\title{
Cohabitation and social engagement
}

\author{
Christoph M. Schimmele \\ Department of Sociology \\ University of Victoria \\ chrissch@uvic.ca \\ Zheng Wu \\ Department of Sociology \\ University of Victoria
}

\begin{abstract}
In Canada, nonmarital cohabitation has become a normative life experience, but there are uncertainties regarding its contribution to social cohesion. This article compares and contrasts cohabitation with marriage (and other marital statuses) on two dimensions of social engagement: social networks and prosocial behaviour. The study employs GSS-17 microdata and logistic regression analysis. The findings illustrate that social engagement is similar among cohabitors and the married.
\end{abstract}

Keywords: cohabitation, marital status, social engagement, social networks, prosocial behaviour.

\section{Résumé}

Au Canada, l'union de fait est devenue une expérience de vie normative, mais ily a des incertitudes quant à sa contribution à la cohésion sociale. Cet article établit une comparaison et montre les contrastes entre le mariage (et autres situations de famille) sur deux dimensions de l'engagement social, c'est-à-dire les réseaux sociaux et le comportement à caractère sociable. L'étude fait appel aux microdonnées GSS-17 et à l'analyse de régression logistique. Les conclusions illustrent que l'engagement social est semblable pour les personnes vivant en union de fait et les personnes mariées.

Mots-clés : cohabitation, situation de famille, engagement social, réseaux sociaux, comportement à caractère social. 


\section{Introduction}

In a generation, cohabitation has transformed from an unconventional marital status into a normative experience. In North America, cohabitation is the modal choice of first union and is also a functional substitute for marriage in some cases (Bumpass et al. 1991; Wu 2000; Manning and Smock 2002). The transnational increases in cohabitation and the concurrent postponement and outright decline of marriage represent a departure from a marriage-centric paradigm (Cherlin 2004; Heuveline and Timberlake 2004; Le Bourdais and Lapierre-Adamcyk 2004). In Canada, cohabitation increased threefold between 1981 and 2001, and presently accounts for 18 per cent of conjugal households (Wu 2007). Many of these unions are transient or transitional arrangements, but a growing proportion are durable, marriage-like relationships, as cohabitation has reached a comparatively high level of social acceptance in Canada.

However, the meaning of "cohabitation" is elusive and complicated to define in precise terms (Guzzo 2009). The literature defines cohabitation in several different respects, including as a precursor to marriage, an advanced stage of dating, an alternative to being single, and a viable alternative to marriage (see Casper and Bianchi 2000; Heuveline and Timberlake 2004; Rindfuss and VandenHeuvel 1990). The heterogeneous nature of cohabitation, in combination with data limitations that hinder attempts to disentangle the different types of cohabitation, continues to obfuscate conceptualizations of its meaning. There is limited consensus on what cohabitation represents vis-à-vis marriage. Even so, there is general agreement that cohabitation is a principal component of the second demographic transition and has pervasive implications for families and kinship (Lesthaeghe and Surkyn 2008).

While consisting of several different types of relationships, ${ }^{1}$ cohabitational unions are similar in terms of their aggregate difference from other marital statuses, such as singlehood (never-married) and marriage. Cohabitation is a distinct form of marital status, and it ought to be conceptualized as such, even though a large number of cohabitations are impermanent arrangements. Cohabitation is irreducible to either a trial marriage or a transitional relationship, especially considering that its prevalence has increased alongside an almost commensurate decline in rates of marriage (see Bumpass et al. 1991). The marriage-like properties of cohabitation (e.g., a common household, a gender division of labor, pooled resources) have motivated a large body of research that examines whether (to what extent) cohabitation is an alternative to marriage and its significance for the formation of families.

To date, most conceptualizations of cohabitation have focused on relationship quality and other dyadic-specific attributes. These conceptualizations are largely based on assessments of the relationship between cohabitational partners, and the literature seldom considers the meaning of cohabitation outside the dyad. ${ }^{2}$ The char-

1. A similar argument could be made about other marital statuses. For example, the status of "never married" could include individuals who are single, have never dated, are engaged to be married, are former long-term cohabitors, etc. The status of "marriage" could represent a first union or a complex union history that includes cohabitation, divorce, and remarriage. Despite this, there is more heterogeneity between marital statuses than within them.

2. Of course, the literature that discusses the implications of cohabitation for children has a broader concern. Our point is that the meaning of cohabitation has generally 
acteristics typical of cohabitation and cohabitors sets these unions apart from marriage for several reasons (Clarkberg et al. 1995; Nock 1995; Brown 2003; Soons and Kalmijn 2009). For example, there are differences between cohabitation and marriage in the depth of commitment to the relationship, expectations between partners/spouses, relationship satisfaction, and personal well-being. On these attributes, marriage tends to be a stronger union than cohabitation. Without doubt, these attributes are fundamental criteria for defining what cohabitation is and is not, and for assessing whether it is a marriage-like relationship or is replacing marriage.

That said, the definition of cohabitation depends on more than the private attitudes, characteristics, and behaviours of cohabitors themselves. The meaning of cohabitation is also a reflection of public circumstances and societal norms, such as the level of acceptance of nonmarital households, the integration of cohabitors into social networks, and the general "embeddedness" of cohabitational relationships. Hence, the social engagement of cohabitors partly determines the meaning of cohabitation, because this is a broad indication of the interface between cohabitation and society. Social engagement refers to social activities and behaviors that generate interpersonal connections and public benefits, including involvement in social networks, participation in communities, volunteering, and reciprocal exchanges (Moore-McBride 2007). These activities form the capacities of modern communities to organize themselves for mutual benefit and social protection, and are cornerstones of social cohesion.

The objective of this study is to describe differences in social engagement (social networks and prosocial behaviour) that correspond to marital status. There is an abundant literature on the personal characteristics of cohabitors, the structural characteristics of cohabitation, and the micro-level implications of cohabitation. Prior studies suggest that cohabitational unions are a somewhat anemic commitment in comparison to marriage, demonstrating that cohabitations tend to be less committed and more instable relationships, and generate fewer relationship-specific benefits (Nock 1995; Smock 2000; Waite and Gallagher 2000). The growth of cohabitation is often interpreted in terms of a corresponding rise in socalled "selfish individualism," and as a propeller of the decline of cohesive families and communities. Though overstated, ${ }^{3}$ this interpretation still raises important questions about whether cohabitation is a solid basis for kinship formation, and whether cohabitors develop the kinds of social networks and social commitments that resemble those of married persons.

As dyadic relationships strengthen (e.g., in the transition from dating to engagement to marriage), there is a corresponding increase in the conjoint social contacts of partners (Milardo 1982). There is a direct association between an individual's level of commitment within their conjugal relationship and the size and composition of their social network. Furthermore, Kearns and Leonard (2004) demonstrate that the degree of network interdependence between partners predicts the chances that the relationship will flourish or deteriorate. Hurlbert and Acock (1990) observe significant differences in the size and composition of social networks between the married, widowed, and unmarried. Their analysis-which

been defined in couple-specific terms, with limited reference to what it means in social terms.

3. See Lewis (2001) for a discussion and critique of this interpretation. 
does not categorize cohabitation as a distinct form of marital status-indicates that the married and widowed have denser, more kin-oriented social networks than the never-married. This marital status difference in social networks translates into a structural difference in social integration, and it could also account for some marital status disparities in well-being.

Conjoint networks of couples represent relationship-specific investments into the union, which pay dividends in the currency of relationship satisfaction, personal well-being, and sources of social resources (Stein and Hunt 2003). These networks embed individuals in a wider set of relationships that increase the importance of the conjugal relationship. For example, conjoint networks can be backstops against union breakdown, inasmuch as these contain social investments that would be irrecoverable post-dissolution, and may contribute to individual-level commitment to the union and a greater motivation to resolve conflicts within the relationship (Milardo 1982). As Huston (2000) illustrates, marital unions are embedded within broad social networks, and individual-level marital behaviors are situated within this context. The personal commitment to marriage reflects the social valorization of marriage (internalized as a moral imperative), and parallels the putative threat of divorce for social cohesion. There is a structural interdependence between the marital dyad and a wider set of social relations, which contributes to the institutionalization of marriage.

In a seminal article, Nock observes that "cohabitation and marriage do not differ so much in terms of ordinary, everyday partnerships as they do with respect to long-term concerns and relationships with people beyond the immediate dyad" (1995: 73; emphasis added). Nock defines cohabitation as an "incomplete institution," which, in part, he attributes to the comparatively weak intergenerational relationships among cohabitors. He demonstrates that cohabitors have poorer relations with their parents (mothers and fathers) than married people, and this implies that cohabitation could be a precarious basis for kinship. In this vein, Smock (2000) comments that the absence of clear institutional norms to regulate the expectations between cohabiting couples and their respective families tends to preclude cohabitors from integration into marriage-like networks, and, presumably, from certain types of social associations and reciprocal exchanges. Hence, a crucial distinction between cohabitation and marriage appears to reside in the development of relationships outside the dyad.

There are good reasons to suspect that cohabitation could involve a different (weaker) form of social engagement than marriage. An emphasis on individualoriented interests and goals influences entrance into cohabitation instead of marriage (Clarkberg et al. 1995). Cohabitors are less committed to the institution of marriage and tend to define marriage in individual-centric (rather than coupleoriented) terms (Thomson and Colella 1992). The extent to which individualistic orientations influence differences between cohabitation and marriage on social engagement is beyond the scope of this paper (data limitations). But the putative individualism of cohabitors is still relevant for our analysis, because it suggests that, on average, these people are comparatively less invested in their unions, and this disinterest could discourage certain aspects of social engagement. In addition, the short-term (instable) nature of cohabitation could also discourage social engagement. As Shapiro and Keyes (2008) suggest, because marriage is a long-term 
social contract and is expected to be a permanent union, married persons are more embedded in social networks than unmarried persons. In contrast, the relative impermanence of cohabitation appears to discourage social investments into these unions (Eggebeen 2005).

For social networks, the following analysis examines marital status differences in the number of close friends and casual friends. These measures of social contacts will provide important insights about differences (or similarities) between cohabitation and marriage regarding the size of social networks, which is a general indication of social connectedness and perhaps also of social integration. The definition (survey measure) of close friends is intended to capture the number of social contacts that are confidants and/or reliable sources of social support. In this respect, this measure is particularly useful for assessing whether cohabitation tends to produce a similar social union as marriage. Besides a conjugal union (or a dyad), marriage represents a social union because it tends to be a foundation for social interconnections between those inside (the couple) and those outside the dyad. $^{4}$

For prosocial behavior, the analysis examines differences in volunteering, helping with social support (from cohabitors to others), and charitable donations. Eisenberg and Mussen define prosocial behavior as "voluntary actions that are intended to help or benefit another individual or group of individuals" (1989: 3). These actions demonstrate an individual's general concern with and personal commitment to group-level well-being, including investments and participation in extended families, community organizations, and other social associations. These actions could be motivated by an altruistic concern for the needs of others, or it could involve a contribution towards a mutual benefit. As marriage is a "rooted" life stage, it often increases social commitments, including to extended family members, neighbors and neighborhood groups, and child-related organizations. The purpose of measuring marital status differences in prosocial behavior is to gauge commensurate differences in levels of social commitment and social cooperation outside the conjugal dyad.

\section{Data and methods}

To describe marital status differences in social engagement, the following analysis utilizes data from the General Social Survey, Cycle 17 (GSS-17). The GSS is a long-term (cross-sectional) survey that collects individual- and household-level data on Canadian adults to monitor social trends and transitions in living conditions (Statistics Canada 2004). The GSS-17 is the first cycle to collect detailed information on social engagement, including social contacts, exchanges of social support, membership in various groups, associations, clubs, and other organizations, volunteering and charitable giving, and civic participation. In addition, the GSS-17 collected information on sociodemographic characteristics such as age, marital status, gender, income, education, housing, and enthocultural background.

4. In some circumstances, an individual can also decrease their involvement in their social network following an increase in romantic involvement, a process termed dyadic withdrawal (Johnson and Leslie 1982). However, this process is selective of certain types of individuals. 
Statistics Canada conducted the GGS-17 between February and December 2003, collecting the data in seven independent samples. The target population for the GSS-17 included all Canadian residents 15 years of age and older from Canada's 10 provinces, but excluded individuals living in the Yukon, Northwest Territories, and Nunavut (remote Northern regions) and full-time residents of institutions. The GSS-17 employed a stratified sampling procedure and a Random Digit Dialing (RDD) method to identify the sample elements (households). Although 98 per cent of Canadian households have telephones, the GSS-17 estimates are weighted to account for households without landline telephones. Using the computer-assisted telephone interviewing (CATI) method, the GSS-17 collected information from a sample of 24,951 individuals living in private households, with an overall response rate of 78 per cent (see Statistics Canada 2004 for complete details on the survey and sample design).

The prevalence of cohabitation becomes increasingly uncommon among middle-aged and older Canadians (see Statistics Canada 2006). The lower prevalence of cohabitation at older ages implies that there could be a selectivity problem that controlling for age group cannot adequately address. This selectivity problem could represent potential age and cohort differences (confounding effects) in the relationship between social engagement and marital status, especially in a cross-sectional research design. For this reason, the study sample is restricted to respondents aged $18-39$ years $(N=9,080)$, for whom cohabitation is a normative experience and cohabitors compose a substantial proportion of the population.

The study considers two dimensions of social engagement. First, social networks, which consists of two dependent variables: number of close friends and casual friends. Each respondent was asked: "How many friends do you have who you feel close to, that is, who you feel at ease with, can talk to about what is on your mind, or call on for help?" For casual friends, the question was: "How many casual friends do you have who are not relatives or close friends?" Count numbers were recorded, but in the public-use file the measure is ordinal: none, 1-2, 3-5, 6-10, 11-20, and 20+. Second, the study measures prosocial behaviour, including volunteering, helping, and donating. These three variables are measured as dummy indicators based on the following questions: (a) "In the past 12 months, did you do unpaid volunteer work for any organization?"; (b) "In the past 12 months did you help anyone [by providing instrumental, emotional, or other support]?"; 5 and (c) "In the past 12 months, did you donate money or goods to any organization or charity, not including membership fees or dues?” Missing values for all dependent variables have been removed from the analysis.

The primary independent variable is marital status: married, separated/divorced, never married, and cohabiting (reference group). The widowed are excluded because of small numbers in the population aged 18-39. Table 1 shows that 37 per cent of the target population are married, 4 per cent are separated/divorced, 45 per cent are never married, and 14 per cent are cohabiting.

While data limitations prohibit an examination of factors (theoretical ideas) that could account for differences in social engagement between cohabitation, marriage, and other marital statuses, the regression analysis introduces controls

5. This measure excludes help provided to co-residents or help provided during volunteer activities. 
Table 1. Definitions and descriptive statistics of the independent variables used in the analysis: Canadian adults (age 18-39), 2003.

\begin{tabular}{|c|c|c|c|}
\hline Variable & Definition & $M$ or $\%$ & S.D. \\
\hline \multicolumn{4}{|l|}{ Marital status } \\
\hline Married & Dummy indicator $(1=$ yes, $0=$ no $)$ & $36.9 \%$ & - \\
\hline Separated/divorced & Dummy indicator $(1=$ yes, $0=$ no $)$ & $4.0 \%$ & - \\
\hline Never married & Dummy indicator $(1=$ yes, $0=$ no $)$ & $44.9 \%$ & - \\
\hline Cohabiting & Reference group & $14.3 \%$ & - \\
\hline \multicolumn{4}{|l|}{ Age } \\
\hline $18-24$ & Reference group & $30.4 \%$ & - \\
\hline $25-29$ & Dummy indicator $(1=$ yes, $0=$ no $)$ & $21.7 \%$ & - \\
\hline $30-34$ & Dummy indicator $(1=$ yes, $0=$ no $)$ & $22.7 \%$ & - \\
\hline $35-39$ & Dummy indicator $(1=$ yes, $0=$ no $)$ & $25.2 \%$ & - \\
\hline Female & Dummy indicator $(1=$ female, $0=$ male $)$ & $49.5 \%$ & - \\
\hline Children under 6 & $\begin{array}{l}\text { Dummy indicator }(1=\text { presence of children } \\
\text { under } 6 \text { years of age, } 0=\text { otherwise })\end{array}$ & $25.3 \%$ & - \\
\hline Number of children & $\begin{array}{l}\text { Number of (dependent) children in the } \\
\text { household }\end{array}$ & & \\
\hline Immigrant & $\begin{array}{l}\text { Dummy indicator }(1=\text { born outside Canada, } \\
0=\text { otherwise })\end{array}$ & $21.0 \%$ & - \\
\hline Quebec & $\begin{array}{l}\text { Dummy indicator }(1=\text { living in Quebec, } \\
0=\text { otherwise })\end{array}$ & $23.0 \%$ & - \\
\hline Rural & $\begin{array}{c}\text { Dummy indicator }(1=\text { living in rural areas, } \\
0=\text { otherwise })\end{array}$ & $16.4 \%$ & - \\
\hline \multicolumn{4}{|l|}{ Religion } \\
\hline Catholic & Dummy indicator $(1=$ yes, $0=$ no $)$ & $37.8 \%$ & - \\
\hline United Church & Dummy indicator $(1=$ yes, $0=$ no $)$ & $5.1 \%$ & - \\
\hline Other Protestant & Dummy indicator $(1=$ yes, $0=$ no $)$ & $18.7 \%$ & - \\
\hline Other religions & Dummy indicator $(1=$ yes, $0=$ no $)$ & $9.0 \%$ & - \\
\hline No religious affiliation & Reference group & $29.5 \%$ & - \\
\hline \multicolumn{4}{|l|}{ Employment status } \\
\hline Attend school & Dummy indicator $(1=$ yes, $0=$ no $)$ & $18.8 \%$ & - \\
\hline Not work outside home & Dummy indicator $(1=$ yes, $0=$ no $)$ & $16.3 \%$ & - \\
\hline Work outside home & Reference group & $64.9 \%$ & - \\
\hline Education & $\begin{array}{l}\text { Education in } 10 \text { levels }(1=\text { elementary or } \\
\text { less, } \ldots, 10=\text { graduate school or more })\end{array}$ & 6.08 & 2.59 \\
\hline Household income & $\begin{array}{l}\text { Household income in } 12 \text { levels }(1=\text { none, } \\
\qquad \ldots, 12=\$ 100 \mathrm{k}+)\end{array}$ & 8.81 & 2.18 \\
\hline Homeownership & $\begin{array}{l}\text { Dummy indicator }(1=\text { someone in the house- } \\
\text { hold owns the dwelling, } 0=\text { renting })\end{array}$ & 0.64 & - \\
\hline Length in neighborhood & $\begin{array}{l}\text { Length of living in the same dwelling in } 6 \\
\text { levels }(1=<6 \text { months, } \ldots, 6=10+\text { years })\end{array}$ & 3.71 & 1.64 \\
\hline Feel safe & $\begin{array}{c}\text { Feel safe walking alone in neighbourhood in } 5 \\
\text { levels, }(1=\text { very unsafe, } \ldots, 5=\text { very safe })\end{array}$ & 4.08 & 1.16 \\
\hline$N$ & & 9,080 & \\
\hline
\end{tabular}

Note: Weighted means and percentages, and unweighted $N$.

for variables that could otherwise influence individual-level differences in social engagement. The purpose of introducing these covariates is to describe the effects of marital status on individual-level differences in social engagement-net of demographic, socioeconomic, and community/neighborhood differences. Table 1 presents the definitions and descriptive statistics for all the independent variables. 
Age is measured as a 4-level categorical variable, ranging from ages 18-24 (reference group) to age 35-39. ${ }^{6}$ The models include dummy variables for sex $(1=$ female), children under 6 years $(1=$ yes $)$, number of children, immigrant status (1=foreign-born), Quebec residence (1=yes), rural residence (1=yes), and homeownership $(1=y e s)$. Religious affiliation is measured in nominal terms: Roman Catholic, United Church, other Protestant, other religions, and no religious affiliation (reference group). Employment status is measured as attending school, not working outside the home, and working outside the home (reference group). Education is measured as a continuous variable that ranges from (1) elementary school or less to (10) some post-graduate education or more. Household income is measured as a continuous variable that ranges from no income (1) to $\$ 100,000$ or more (12). Length of neighborhood residence is measured as a continuous variable that ranges from (1) $<6$ months to (6) $10+$ years. Neighborhood safety is measured as a continuous variable based on the question, "How safe do you feel from crime walking alone in your area after dark?" The responses ranged from (1) "very unsafe" to (5) "very safe."

Regression analysis uses the logistic approach for modeling marital status differences in social engagement, because logistic regression is a well-understood and well-suited method for binary and ordinal data (see Agresti 2002). ${ }^{7}$ For this paper, ordered and binary logit models are estimated using the Logistic Procedure in SAS 9.1. The parameters are estimated using the maximum likelihood (ML) method, which involves an iterative algorithm. For goodness-of-fit statistics, the tables include twice the negative of the log likelihood (for the final model, including intercept and all covariates), as well as Akaike's information criterion (AIC) and the Schwartz criterion (SC), also known as the Bayesian information criterion (BIC). The larger the log likelihood (chi square) value, the smaller the information measures, and the better the fit.

\section{Results}

As noted above, there is a plausible rationale to anticipate an association between marital status (cohabitation versus marriage) and social engagement. Table 2 offers a bivariate illustration of the association between marital status and two dimensions of social engagement: social networks and prosocial behavior. There is a significant effect of marital status on number of close friends and casual friends ( $p<.001$ for both associations). The married appear to have larger networks of close friends, but this difference between cohabitation and marriage is small.

6. Single years of age (a continuous variable) is unavailable in the public-use datafile, but there is little reason to suspect that this more refined measure would influence the relationship between marital status and social engagement. Measured as a categorical variable, age could actually better capture the effects of lifecycle stages (or cohort effects) on social engagement.

7. The reason for using the logistic regression in the analysis is the ease of interpreting (transformed) regression coefficients as odds ratios, which are obtained through the antilog of logit coefficients $(e \beta)$. For the ordered logit model, the odds ratios can be interpreted as the odds of being in a higher category (rather than being in a lower category) for a one-unit increase in the independent variable. For the binary logit model, the odds ratios represent the odds of $Y=1$ rather than $Y=0$ for a one-unit increase in the independent variable. 
Table 2. Study indicators for social engagement by marital status: Canadian young adults (18-39).

\begin{tabular}{|c|c|c|c|c|c|}
\hline & \multicolumn{4}{|c|}{ Marital status } & Chi square \\
\hline Social engagement & Married & Cohabiting & Sep/Div & Nev mar & $d f$ \\
\hline \multicolumn{6}{|l|}{ Number of close friends } \\
\hline None & 4.1 & 3.8 & 1.8 & 4.1 & \\
\hline $1-2$ & 24.4 & 23.2 & 17.8 & 27.2 & \\
\hline $3-5$ & 43.6 & 49.5 & 43.7 & 44.5 & \\
\hline $6-10$ & 19.8 & 18.7 & 27.4 & 19.4 & 187.1804 \\
\hline $11-20$ & 6.3 & 3.8 & 7.4 & 3.9 & $(d f=15)$ \\
\hline $20+$ & 1.8 & 1.1 & 2.0 & 0.9 & $N=9048$ \\
\hline \multicolumn{6}{|l|}{ Number of other friends } \\
\hline None & 3.7 & 5.0 & 2.8 & 4.0 & \\
\hline $1-2$ & 3.2 & 3.4 & 2.2 & 3.5 & \\
\hline $3-5$ & 11.4 & 13.4 & 8.7 & 13.9 & \\
\hline $6-10$ & 23.7 & 21.3 & 21.4 & 23.9 & 88.4 \\
\hline $11-20$ & 30.7 & 31.7 & 32.7 & 30.6 & $(d f=15)$ \\
\hline $20+$ & 27.3 & 25.2 & 32.2 & 24.1 & $N=8941$ \\
\hline \multicolumn{6}{|l|}{ Unpaid volunteering } \\
\hline$(1=$ yes $)$ & 35.4 & 32.0 & 32.5 & 21.5 & $\begin{array}{l}83.1 \\
(d f=3) \\
N=9019\end{array}$ \\
\hline \multicolumn{6}{|l|}{ Help someone } \\
\hline$(1=$ yes $)$ & 81.0 & 86.8 & 86.4 & 84.0 & $\begin{array}{l}\quad 41.6 \\
(d f=3) \\
N=9020\end{array}$ \\
\hline \multicolumn{6}{|l|}{ Donated money/goods } \\
\hline$(1=$ yes $)$ & 78.2 & 68.4 & 60.1 & 67.9 & $\begin{array}{l}274.6 \\
(d f=4) \\
N=9009\end{array}$ \\
\hline
\end{tabular}

Note: Weighted percentages.

There are also marital status differences in volunteering, helping, and donating $(p<.001$ for all 3 associations). The bivariate results show that 35 per cent of married, 33 per cent of separated/divorced, and 22 per cent of never-married people volunteered in the past 12 months. This compares with 32 per cent of cohabitors, which is a somewhat lower proportion than the married. The difference between cohabitation and marriage on helping could, however, counterbalance this difference in volunteering, as a higher proportion of cohabitors helped others. About 87 per cent of cohabitors helped, in comparison to 81 per cent of the married. This compares with 86 per cent of separated/divorced and 84 per cent of never-married people. A higher proportion of the married (78 per cent) donated to charities and/or other organizations than cohabitors (68 per cent), the separated/divorced (60 per cent), and the never-married (68 per cent).

Table 3 presents the odds ratios from ordered logistic regressions for social network indicators. There is a significant marital status effect on the number of close friends. Our findings demonstrate that the married have fewer close friends than cohabitors. This marital status difference is net of selected control variables. The never-married also have smaller numbers of close friends. In other words, cohabitors have comparatively larger social networks that are composed of close 
Table 3. Estimated odds ratios from ordered logistic regressions for social network indicators Canadian young adults (aged 18-39), 2003.

\begin{tabular}{|c|c|c|}
\hline \multirow{2}{*}{$\begin{array}{l}\text { Variable } \\
\text { Marital status }\end{array}$} & \multicolumn{2}{|c|}{ Network indicators } \\
\hline & & \\
\hline Married & $0.821 * * *$ & 0.962 \\
\hline Separated/divorced & 0.854 & 1.004 \\
\hline Never married & $0.750 * * *$ & $0.876^{*}$ \\
\hline Cohabiting ${ }^{\mathrm{a}}$ & & \\
\hline \multicolumn{3}{|l|}{ Age } \\
\hline \multicolumn{3}{|l|}{$18-24^{\mathrm{a}}$} \\
\hline $25-29$ & $0.857^{*}$ & $0.721 * * *$ \\
\hline $30-34$ & $0.709 * * *$ & $0.639 * * *$ \\
\hline $35-39$ & $0.681 * * *$ & $0.645 * * *$ \\
\hline Female $(1=$ yes $)$ & $0.864 * * *$ & $0.755 * * *$ \\
\hline Children under $6(1=y e s)$ & 1.048 & 0.949 \\
\hline Number of children in household & $0.901 * * *$ & 0.997 \\
\hline Immigrant $(1=$ yes $)$ & $0.665 * * *$ & $0.719 * * *$ \\
\hline Quebec $(1=$ yes $)$ & $0.533 * * *$ & $0.574 * * *$ \\
\hline Rural $(1=$ yes $)$ & $1.152 * *$ & 1.104 \\
\hline \multicolumn{3}{|l|}{ Religion } \\
\hline Catholic & $0.843 * * *$ & $0.886^{*}$ \\
\hline United Church & 1.063 & 0.974 \\
\hline Other Protestant & 1.028 & 1.070 \\
\hline Other religions & 0.897 & $0.763 * *$ \\
\hline No religious affiliation $^{\mathrm{a}}$ & & \\
\hline \multicolumn{3}{|l|}{$\begin{array}{l}\text { No religious atnliation } \\
\text { Employment status }\end{array}$} \\
\hline Attend school & $1.172 *$ & 1.081 \\
\hline Not work outside home & 0.939 & $0.770 * * *$ \\
\hline Work outside home ${ }^{\mathrm{a}}$ & & \\
\hline Education & $1.111 * * *$ & $1.060 * * *$ \\
\hline Household income & $1.066^{* * *}$ & $1.091 * * *$ \\
\hline Homeownership (1 = yes) & 0.949 & 0.955 \\
\hline Length in neighborhood & 1.008 & 1.015 \\
\hline Feel safe & $1.101 * * *$ & $1.084 * * *$ \\
\hline Intercept6 & $-5.091 * * *$ & $0.189 * * *$ \\
\hline Intercept5 & $-3.474 * * *$ & $0.745^{*}$ \\
\hline Intercept4 & $-1.752 * * *$ & $2.525 * * *$ \\
\hline Intercept 3 & $0.319 *$ & $8.093 * * *$ \\
\hline Intercept 2 & $2.753 * * *$ & $15.526 * * *$ \\
\hline AIC & 24098 & 26569 \\
\hline $\mathrm{BIC}$ & 24297 & 26767 \\
\hline-2 Log Likelihood & 24042 & 26513 \\
\hline$N$ & 9,048 & 8,473 \\
\hline
\end{tabular}

${ }^{a}$ Reference category.

$* \mathrm{p}<.05 ; * * \mathrm{p}<.01 ; * * * \mathrm{p}<.001$ (two-tailed test).

friends. However, cohabitors do not have significantly more casual friends than the married or the separated/divorced. The never-married also have significantly fewer casual friends than cohabitors. For social networks, these findings suggest that cohabitors are neither similar to the married nor the never-married.

Table 4 presents the odds ratios for the selected indicators of prosocial behavior. For volunteering, there is a significant difference between cohabitors and the never-married, but not the other marital status groups. The never-married have a lower likelihood of volunteering than cohabitors. Cohabitors have a higher likelihood of providing help (social support) than both the married and the nevermarried. In comparison with the married, cohabitors tend to donate less.

Table 5 presents the odds rations of the interaction effects of marital status with gender and age. Panel A presents the interaction effects on other friends and Panel B 
Table 4. Estimated odds ratios from logistic regressions for prosocial behaviour indicators Canadian young adults (aged 18-39), 2003.

\begin{tabular}{|c|c|c|c|}
\hline \multirow{2}{*}{ Variable } & \multicolumn{3}{|c|}{ Prosocial behaviour } \\
\hline & Volunteer & Give help & Donate \\
\hline \multicolumn{4}{|l|}{$\overline{\text { Marital status }}$} \\
\hline Married & 1.061 & $0.748 * *$ & $1.477 * * *$ \\
\hline Separated/divorced & 1.075 & 1.178 & 1.218 \\
\hline Never married & $0.691 * * *$ & $0.775^{*}$ & 1.044 \\
\hline Cohabiting $^{\mathrm{a}}$ & & & \\
\hline \multicolumn{4}{|l|}{ Age } \\
\hline $18-24^{a}$ & & & \\
\hline $25-29$ & 0.860 & $0.681 * * *$ & 1.151 \\
\hline $30-34$ & 0.878 & $0.677 * * *$ & $1.214^{*}$ \\
\hline $35-39$ & 0.901 & $0.616 * * *$ & $1.365^{* * *}$ \\
\hline Female $(1=y e s)$ & $1.213 * * *$ & $1.205 * *$ & $1.604 * * *$ \\
\hline Children under $6 \quad(1=y e s)$ & $0.567 * * *$ & 0.922 & 1.151 \\
\hline Number of children in household & $1.338 * * *$ & $1.099 *$ & 1.053 \\
\hline Immigrant $(1=y e s)$ & $0.646 * * *$ & $0.479 * * *$ & $0.713 * * *$ \\
\hline Quebec ( $1=$ yes) & $0.573 * * *$ & 0.973 & 0.911 \\
\hline Rural $(1=$ yes $)$ & $1.289 * * *$ & 1.036 & $0.876^{*}$ \\
\hline \multicolumn{4}{|l|}{ Religion } \\
\hline Catholic & 0.931 & 1.067 & $1.263 * * *$ \\
\hline United Church & $1.262 *$ & 1.119 & $1.773 * * *$ \\
\hline Other Protestant & $1.443 * * *$ & $1.291 * *$ & $1.481 * * *$ \\
\hline Other religions & 0.914 & 0.957 & 1.020 \\
\hline No religious affiliation ${ }^{\mathrm{a}}$ & & & \\
\hline \multicolumn{4}{|l|}{ Employment status } \\
\hline Attend school & $1.947 * * *$ & 1.020 & $0.835^{*}$ \\
\hline Not work outside home & $1.262 * * *$ & 0.906 & $0.660 * * *$ \\
\hline Work outside home ${ }^{\mathrm{a}}$ & & & \\
\hline Education & $1.121 * * *$ & $1.088 * * *$ & $1.151^{* * *}$ \\
\hline Household income & $1.051 * * *$ & 1.031 & $1.088 * * *$ \\
\hline Homeownership (1 = yes) & 1.040 & 0.976 & $1.199 * *$ \\
\hline Length in neighborhood & 0.995 & 0.986 & 1.002 \\
\hline Feel safe & 1.034 & 0.974 & 1.030 \\
\hline Intercept6 & $-2.177 * * *$ & $1.564 * * *$ & $-1.534 * * *$ \\
\hline AIC & 10754 & 7403 & 10096 \\
\hline $\mathrm{BIC}$ & 10924 & 7573 & 10267 \\
\hline-2 Log Likelihood & 10706 & 7355 & 10048 \\
\hline $\bar{N}$ & 9,019 & 9.020 & 9,009 \\
\hline
\end{tabular}

${ }^{\mathrm{a}}$ Reference category.

$* \mathrm{p}<.05 ; * * \mathrm{p}<.01 ; * * * \mathrm{p}<.001$ (two-tailed test).

the interaction effects on volunteering. These were the only significant interaction effects observed. Panel A demonstrates that cohabiting men have significantly more casual friends than men and women in all other marital status groups, with the exception of separated/divorced men. The latter group has more casual friends in comparison to cohabiting men. In comparison with 18-24-year-olds, all other age groups across all other martial statuses have fewer casual friends. Cohabitors have more casual friends than the married among the 18-24 and 25-29 age groups. However, the married appear to gain the advantage over time, and possess more casual friends at older ages. Across all marital statuses, women tend to have fewer casual friends than men.

In Table 5, Panel B demonstrates that cohabiting men volunteer less than their married and previously married counterparts, but more than never-married men. In contrast, cohabiting women have the highest likelihood of volunteering across gender and marital status. There is no clear age pattern in volunteering, but cohabitors aged 18-24 have a higher likelihood of volunteering than almost everyone else, except for married 35-39-year-olds and previously married 30-34-year-olds. 
Table 5. Estimated odds ratios of the interaction effects of marital status with gender and age on "Other Friends" and "Volunteer": Canadian young adults (aged 18-39), 2003.

\begin{tabular}{lcccc}
\hline \multicolumn{1}{c}{ Variable } & Married & Cohabiting & $\begin{array}{r}\text { Separated/ } \\
\text { divorced }\end{array}$ & $\begin{array}{r}\text { Never } \\
\text { married }\end{array}$ \\
\hline $\begin{array}{l}\text { Panel A: Other Friends (ordered logit) } \\
\text { Women }\end{array}$ & 0.765 & 0.760 & 0.662 & 0.612 \\
Men & 0.894 & 1.000 & 1.360 & 0.973 \\
Age & & & & \\
18-24a & 0.688 & 1.000 & 0.843 & 0.653 \\
25-29 & 0.606 & 0.698 & 0.486 & 0.649 \\
30-34 & 0.582 & 0.527 & 0.675 & 0.648 \\
35-39 & 0.636 & 0.547 & 0.615 & 0.470 \\
Panel B: Volunteer (binary logit) & & & & \\
Women & 1.353 & 1.437 & 1.404 & 0.798 \\
Men & 1.232 & 1.000 & 1.257 & 0.910 \\
Age & & & & \\
$18-24^{\mathrm{a}}$ & 0.843 & 1.000 & 0.369 & 0.810 \\
25-29 & 0.860 & 0.925 & 0.714 & 0.531 \\
$30-34$ & 0.890 & 0.807 & 1.234 & 0.711 \\
$35-39$ & 1.034 & 0.815 & 0.899 & 0.525 \\
\hline
\end{tabular}

Note: Models control for all explanatory variables shown in Table 3. Each set of the interaction terms were tested as a block on the basis of LR test $(p<.05)$. The full tables are available from the authors upon request.

\section{Discussion and limitations}

The study examined the relationship between marital status and two dimensions of social engagement: social networks (number of close friends and casual friends) and prosocial behavior (volunteering, social support, and donating). The influence of marital status on social engagement is an important consideration, because social networks link individuals to their communities, and prosocial behaviours demonstrate a concern for community well-being. Our main interest was comparing cohabitation to marriage in these terms. This preceding descriptive analysis offers insights into the meaning of cohabitation in the social context. The empirical analysis explored the association between cohabitation and social engagement. Although our analysis does not resolve what explains marital status differences in social engagement, it nonetheless describes some important distinctions between cohabitation and marriage.

The take-away conclusion is that cohabitors are not less engaged that the married, at least for the indicators of social engagement considered above. In comparison to the married, cohabitors have larger friend-based social networks, have a similar likelihood of volunteering, and have a higher likelihood of providing social support to people outside their households. Hence, cohabitors behave more like the married than singles across these aspects of social engagement. These findings suggest that the "selfish individualism" that is sometimes attributed to the growth of cohabitation could be unwarranted. Whatever their reasons for cohabiting, co- 
habitors do not appear to be hunkering down to behave in a selfish manner, according to our findings.

Our analysis has some important limitations. First, the empirical analysis is based on cross-sectional data, which is unsuitable for determining the effect of marital status on changes in social engagement. That is, our analysis cannot describe how transitions in marital status (e.g., never married to cohabiting) influence increases (or decreases) in social engagement. Longitudinal data is needed to disentangle whether marital status differences in social engagement are associated with a selection effect, a causation effect, or a combination of both. Second, the analysis was also limited because information on length of union was unavailable. Length of union is, of course, a major consideration, and it would be reasonable to argue that our results could reflect a high proportion of short-term cohabitations in the study sample. In accordance, perhaps our findings are an inapt description of long-term cohabitations.

\section{References}

Agresti, A. 2002. Categorical Data Analysis. 2nd edn. Hoboken, NJ: Wiley.

Brown, S.L. 2003. Relationship quality dynamics of cohabiting unions. Journal of Family Issues 24:583-601.

Bumpass, L.L., J.A. Sweet, and A. Cherlin. 1991. The role of cohabitation in declining rates of marriage. Journal of Marriage and Family 53:913-27.

Casper, L.M., and S.M. Bianchi. 2002. Continuity and Change in the American Family. Thousand Oaks, CA: Sage.

Cherlin, A.J. 2004. The deinstitutionalization of American marriage. Journal of Marriage and Family 66:848-61.

Clarkberg, M., R.M. Stolzenberg, and L.J. Waite. 1995. Attitudes, values, and entrance into cohabitational versus marital unions. Social Forces 74:609-34.

Eggebeen, D.J. 2005. Cohabitation and exchanges of support. Social Forces 83:1097-110.

Eisenberg, N., and P.H. Mussen. 1989. The Roots of Prosocial Behavior in Children. Cambridge (UK): Cambridge University Press.

Guzzo, K.B. 2009. Marital intentions and the stability of first cohabitations. Journal of Family Issues 30:179-205.

Heuveline, P., and J.M. Timberlake. 2004. The role of cohabitation in family formation: The United States in comparative perspective. Journal of Marriage and Family 66:121430.

Hurlbert, J.S., and A.C. Acock. 1990. The effects of marital status on the form and composition of social networks. Social Science Quarterly 71:163-74.

Huston, T.L. 2000. The social ecology of marriage and other intimate unions. Journal of Marriage and Family 62:298-320.

Johnson, M.P., and L. Leslie. 1982. Couple involvement and network structure: A test of the dyadic withdrawal hypothesis. Social Psychology Quarterly 45:34-43.

Kearns, J.N., and K.E. Leonard. 2004. Social networks, structural interdependence, and marital quality over the transition to marriage: A prospective analysis. Journal of Family Psychology 18:383-95.

Le Bourdais, C., and E. Lapierre-Adamcyk. 2004. Changes in conjugal life in Canada: Is cohabitation progressively replacing marriage? Journal of Marriage and Family 66:929-42. 
Lesthaeghe, R., and J. Surkyn. 2008. When history moves on: The foundations and diffusion of the second demographic transition, in International Family Change: Ideational Perspectives, edited by R. Jayakody, A. Thornton, and W. Axinn. New York: Lawrence Erlbaum Associates, pp. 81-118.

Lewis, J. 2001. Debates and issues regarding marriage and cohabitation in the British and American literature. International Journal of Law, Policy, and the Family 15:159-84.

Manning, W., and P. Smock . 2002. First comes cohabitation and then comes marriage? Journal of Family Issues 23:1065-87.

Milardo, R.M. 1982. Friendship networks in developing relationships: Converging and diverging social environments. Social Psychology Quarterly 45:162-72.

Moore-McBride, A. 2007. Civic engagement, older adults, and inclusion. Generations 30:66-71.

Nock, S.L. 1995. A comparison of marriages and cohabiting relationships. Journal of Family Issues 16:53-76.

Rindfuss, R., and A. Van den Heuvel. 1990. Cohabitation: A precursor to marriage or an alternative to being single? Population and Development Review 16:703-26.

Shapiro, A., and C.L.M. Keyes. 2008. Marital status and social-well being: Are the married always better off? Social Indicators Research 88:329-46.

Smock, P.J. 2000. Cohabitation in the United States: An appraisal of research themes, findings, and implications. Annual Review of Sociology 26:1-20.

Soons, J.P.M., and M. Kalmijn. 2009. Is marriage more than cohabitation? Well-being differences in 30 European countries. Journal of Marriage and Family 71:1141-57.

Statistics Canada. 2004. 2003 General Social Survey, Cycle 17: Social Engagement. Ottawa: Minister of Industry.

Statistics Canada. 2006. Annual Demographic Statistics, 2005. Ottawa: Minister of Industry.

Stein, C.H., and M.G. Hunt. 2003. Social networks, in International Encyclopedia of Marriage and Family, vol. 4., edited by J.J. Ponzetti. 2nd edn. New York: Macmillan, pp. 1540-54.

Thomson, E., and U. Colella. 1992. Cohabitation and marital stability: Quality or commitment? Journal of Marriage and Family 54:259-67.

Waite, L.J., and M. Gallagher. 2000. The Case for Marriage: Why Married People are Happier, Healthier, and Better Off Financially. New York: Doubleday.

Wu, Z. 2000. Cohabitation: An Alternative Form of Family Living. Don Mills, ON: Oxford University Press.

2007. Shacked up. Paper presented to the Breakfast on the Hill Seminar, Canadian Parliament, Ottawa (October 23). 